\title{
THE EFFECT OF REPETITION EXERCISE METHOD AND INTENSIVE INTERVAL EXERCISE METHOD ON THE STUDENTS' 100 METER SPRINTING ABILITY AT SMP N 1 PARIAMAN
}

\author{
Kamal Firdaus \\ State University of Padang, Komp. Parupuk Raya B 36 Tabing Padang, West Sumatera 25171 \\ dr.kamalfirdaus.mkes.aifo@gmail.com
}

\begin{abstract}
This research was derived from the problems indicating that the students had lack of capability in 100 meter sprinting. This could be seen from the result of local sport competition held annually. This research sought to explain the improvement of the students' 100 meter sprinting ability by using Repetition Exercise Method and Intensive Interval Method. The subject of the research was 22 students at SMP N 1 Pariaman. They were chosen based on their ability in 100 meter sprinting which was lower compared to those from other schools. This was an experimental research which applied quantitative approach. The research was conducted in 16 meetings from May to June 2014. The data gathered were in the form of quantitative data. They were obtained through 100 meter sprinting test. The results of data analysis revealed that: (1) the value of $t_{\text {calculated }}$ gotten by applying Repetition Exercise Method was higher (12.14) than that of $t_{\text {table }}$ (1.812) indicating that the use of that method significantly exerted an influence upon the students' 100 meter sprinting ability at SMP Negeri 1 Pariaman, (2) the value of $t_{\text {calculated }}$ gotten by applying Intensive Interval Method was higher (3.27) than that of $t_{\text {table }}(1.812)$ indicating that the use of that method significantly exerted an influence upon the students' 100 meter sprinting ability at SMP Negeri 1 Pariaman, and (3) there was no significant different between the use of Repetition Exercise Method and Intensive Interval Method at SMP Negeri 1 Pariaman in which the value of $t_{\text {calculated }}(0.28)$ was higher than $t_{\text {table }}(1.860)$.
\end{abstract}

\section{A. INTRODUCTION}

Sports could be regarded as an important part in establishing qualified human resource. Health is highly essential for the growth of intellectual, physical, emotional and social intelligences. Therefore, sports essentially place an important position in educational program both in and out of school. It should be developed by socializing the sports and sporting the people. This would make sports become important in a society. Sports, actually, have specific purposes including (1) recreation, (2) education, (3) physical fitness, and (4) merit (Sajoto, 1988:1-2).

Sport activities are taught from elementary school to university level. It is included in the school curriculum as the supporting factor for the growth and the improvement of the students' physical fitness. In addition, sports are intended to grow the students' delight to and to increase the students' achievement in.

Sport activities frequently become an annual event for the students in which it is held in a district such as in Pariaman. These activities are held by schools. The event becomes a medium for the students to apply what they have learnt at school and to enhance their creativity and physical health. Introducing sports in a formal institution such as Junior High School is done through extracurricular or self-development program. Selfdevelopment program is medium for the students to do activities beyond school time and during holiday, or in a particular time either regularly or occasionally. These activities are intended to support the intra-curricular ones so that the students could gain a good achievement in sports especially in the events held in Kota Pariaman.

The most favorable branch of sports for the Senior High School students in the Local Sport Event for the Students is athletics. Jonath et.al (1987:1) state that "Athletics is a branch of sport requiring strength, skill, and speed that includes walking, running, jumping and throwing. The four mentioned are regarded as the oldest and the most natural exercises enabling people to develop their primitive instinct to move. Athletics exercise could repair blood circulation and nerve system, and build physique such as energy, speed, fluency of movement, dexterity and so on. In addition, movements in athletics are regarded as the basis for other movements in various branches of sports. Hence, it is reasonable to say that athletics is the mother of the other branches of sports.

The competition in athletics covers running, jumping and throwing. Running is the main branch of athletics. 


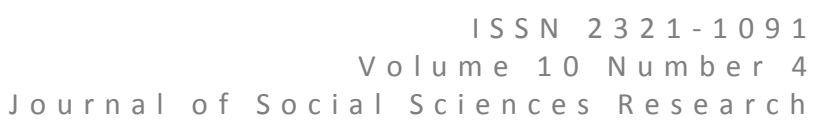

Running is an innate ability. It is done by putting one foot in front of the other with faster movements. The numbers competed in running are sprinting, middle distance running and long distance running. Meanwhile the number competed in Local Sport Competition for the Students is 100 meter sprinting.

Based on the observations done, it was revealed that the Sport teachers who are also the coaches are only able to produce athletes participating in school competition. It could be seen in the Sport Competition for the Students in 2013 that none of the students won any awards in running and they always got lost. Ignoring this problem would make the athletes of SMP N 1 Pariaman unable to get any achievements and could not compete with other schools either for regional or national championship. The data of the Local Championship in 2013 show that SMP N 1 Pariaman was on the lowest position compared to other schools.

The results of the interview done with the Physical, Sport and Health Education teachers also indicated that lately, the students' achievement got decreased. The students seemed to have less understanding on the techniques of 100 meter sprinting. In addition, the physical factor also became one of the indicators discussed in this research. While doing the sport activities, many students complained on their ability. Furthermore, the couches or the teachers applied less varied methods and merely focused on 100 meter sprinting topic in presenting the learning materials which then led the process to boredom.

The Physical, Sport and Health Education teacher accompanied with the principal stated that "for two or three years to go, SMP N 1 Pariaman has to be on the top 3 in the annual competition. Therefore, the teachers or the coaches have to work hard to lead the students to gain the expected achievement".

The process of coaching and training previously was very alarming in which the sport activities were only done once in a week and supported by an extracurricular activity. Regarded to this phenomenon, it is certainly difficult for the students to gain an achievement in sports. It seemed to be impossible for the students to achieve better results if they only had single meeting in a week.

The learning process did not have the students to move actively. The students were only demanded to run and did not experience other activities facilitating them to improve their achievement in sprinting. This then made the students less understand the movements in running well and effectively. They merely knew what running is, but did not understand various techniques in starting and several styles of running. Consequently, the students could not achieve the maximum result in sprinting.

This research used intensive interval method and repetition method. The two are considered as very appropriate to increase the students' 100 meter sprinting ability at SMP N 1 Pariaman as they could produce speed power. These methods also could be used to develop the students' cyclic and acyclic movement, and acceleration. Therefore, it is necessary to conduct a research by making use of the two methods.

Athletics is a sport contested, both nationally and internationally. It is a sport that is divided into several numbers in the competition, one of which is sprinting (short distance running). In athletics, when the exercises are done seriously, they would lead to a good result. At school, in fact, the basic techniques of athletics have already been taught. One of the numbers competed in the championship is 100 meter sprinting (Syafaruddin, 2012: 5). It is done by using full or maximum speed along the distance.

Sprinting is an anaerobic sport, and biomechanically, it is a cyclic sport consisting of three phases of movement, namely: initial phase (preparation before starting), main phase (get ready to run), and final phase (posture when entering the finish line). In sprinting, commonly, the runners do squat starting in which they squat over the starting blocks before running.

To do sprinting, the runners must understand the principles of the running technique and also should know the factors that could be developed in the short distance sprinting. According to Syafruddin (2012: 97), the factors that could be developed to increase the sprinting speed are speed of reaction (in starting), speed power, maximum movement speed, and speed endurance.

Repetition exercise method is a method that puts more emphasis on very high intensity tasks for which the runners are given a full break with a longer period. Between the repetition of the exercise materials and the high intensity of task, there are some intervals that give complete recovery (Syafruddin, 1992: 199).

Interval exercise method is done by doing exercise interspersed with a break or recovery (Hairy 1989: 234). Through this method, running is divided or split into shorter distance and interspersed by a break as a recovery between the parts of the section. According to Suharno (1993: 12), "interval exercise refers to a method of exercise done with a break between each repetition". 


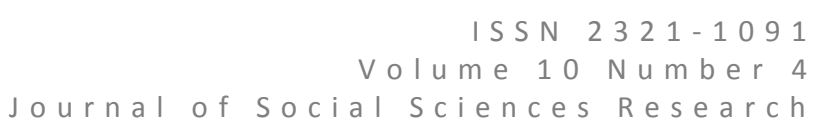

\section{B. METHOD}

This was a quasi experimental research. The independent variables in this research were interval intensive exercise method and repetition exercise method. Meanwhile the dependent variable was the students' 100 meter sprinting ability at SMP N 1 Pariaman.

The population of the research was the students at SMP N 1 Pariaman taking 100 meter sprinting as an extracurricular activity. By using Purposive Sampling technique, 22 male students were chosen as the sample. They then were divided into two groups in which each group consisted of 11 students. To ensure that the two sample groups were homogenous, they were divided by making use of ordinary matched pairing method. In order to determine which group would be treated by using interval method and which group would gain repetition method, a lot was drawn. Prior to the treatment, a pretest was administered to the samples.

The data gotten from the pretest and the posttest were analyzed by using normality test and t-test. The normality test was done by using Lilliefors intended to reveal whether the data gathered were normal or not. The next step was conducting homogeneity test to see the homogeneity of the data.

\section{FINDINGS AND DISCUSSIONS}

Based on the result of the normality test, it was found out that the value of $L_{\text {observation }}\left(L_{0}\right)$ was smaller than that of $L_{\text {table }}$ on the significance level 0.05 . Thus, it was concluded that the data obtained in this research were normally distributed.

Furthermore, the result of homogeneity test showed that the value of $F_{\text {calculated }}(1.15)$ was smaller than $F_{\text {table }}$ (3.36) on the degree of freedom (n1-1), (n2-1) and the significance level of the respective variable was higher than 0.05 . This result suggested that the data gained were homogenous.

Based on the results of the normality and homogeneity tests, the following hypotheses were confirmed:

1. The value of $t_{\text {calculated }}$ (12.14) was higher than that of $t_{\text {table }}(1.812)$ indicating that the first hypothesis was accepted. This result revealed that the repetition exercise method significantly affected that students' 100 meter sprinting ability at SMP N 1 Pariaman.

2. The value of $t_{\text {calculated }}$ (3.27) was higher than that of $t_{\text {table }}(1.812)$ indicating that the second hypothesis was accepted. This result suggested that the use of interval intensive method significantly exerted an influence upon the students' 100 meter sprinting ability at SMP N 1 Pariaman.

3. The value of $t_{\text {calculated }}(0.28)$ was smaller than $t_{\text {table }}(1.860)$ indicating that the third hypothesis was rejected. This result implied that there was no significant difference between the use of repetition exercise method and interval intensive method. This result showed that the two methods exerted an influence upon the students' 100 meter sprinting ability at SMP N 1 Pariaman.

The result of pretest showed that the average score of the students' 100 meter sprinting ability was 16.11 , and after the treatment given, their average score improved to 15.26. From this result, it was concluded that the use of repetition exercise method influenced the students' 100 meter sprinting ability at SMP N 1 Pariaman. This finding was supported by the result of $t$-test indicating that the value of $t_{\text {calculated }}(12.14)$ was higher than that of $t_{\text {table }}(1.812)$ on the significance level $\alpha=0.05$.

One of the methods used to improve the students' 100 meter sprinting ability was repetition exercise. Hadisasmita (1992:26) explains that repetition exercise method comprises of particular exercises which are done repeatedly and intermitted by a full break.

Based on the research findings, it is concluded that the repetition exercise method could increase the students' 100 meter sprinting ability. Therefore, it is suggested to the couches and the teachers to apply this method to enhance the students' ability in 100 meter sprinting.

The results of the research also proved that the use of intensive interval exercise method affected the students' 100 meter sprinting ability at SMP N 1 Pariaman. Before the treatment was given, a pretest was administered. The result of the test showed that the students' average score in 100 meter sprinting was 16.12. After the interval intensive method was applied, the students' 100 meter sprinting ability increased into 15.17. This result suggested that the application of interval intensive method influenced the students' 100 meter sprinting ability at SMP N 1 Pariaman. This finding was strengthened by the result of t-test showing that the value of $t_{\text {calculated }}$ (3.27) was higher than $t_{\text {table }}(1.812)$ on the significance level $\alpha=0.05$.

To improve the students' 100 meter sprinting ability, interval intensive exercise method could be applied. According to Suharno (1993:35), "interval running exercise is the exercise done until the players achieve the high period and it is intermitted by a short break, and then the exercise is again repeated". The basic 
principle of interval exercise is the transition from burdening to releasing or from working to resting which is done one after another (Jonath in Syafruddin, 1999:113).

Based on the research conducted, it is concluded that the interval intensive exercise method could improve the students' 100 meter sprinting ability. Therefore, it is recommended to the couches and the teachers to choose and apply this method as the form of exercise in 100 meter sprinting.

In order to see the difference between the effect of using repetition exercise method and that of using interval intensive exercise method on the students' 100 meter sprinting ability, the value of t-test was considered. As the value of $t_{\text {calculated }}(0.28)$ was smaller than $t_{\text {table }}(1.860)$, Ha was accepted. This result indicated that there was no significant difference between the use of repetition exercise method and interval intensive exercise method on the students' 100 meter sprinting ability at SMPN 1 Pariaman.

From the results, it is summarized that the two methods are similarly effective to be used to increase the students' 100 meter sprinting ability at SMPN 1 Pariaman.

\section{CONCLUSION}

Based on the results of data analysis and discussions, the following conclusions were drawn:

1. Repetition exercise method significantly exerts an influence upon the students' 100 meter sprinting ability at SMP N 1 Pariaman.

2. Interval intensive exercise method significantly affects the students' 100 meter sprinting ability at SMP N 1 Pariaman.

3. The repetition exercise method and the Interval intensive exercise method are similarly effective to increase the students' 100 meter sprinting ability. In other words, there are no significant difference between the use of repetition exercise method and repetition exercise method.

\section{E. SUGGESTIONS}

Based on the conclusions and the implications above, it is suggested to:

1. The teachers or the couches to have well designed learning program to get maximum result in 100 meter sprinting.

2. The students to take an extracurricular activity so that they could perform the two methods seriously in order to improve their 100 meter sprinting ability.

3. The upcoming researchers to apply similar methods to other groups with a larger number of participants.

\section{REFERENCES}

1. Hadisasmita, MY. 1992. Olahraga Pilihan Atletik. Jakarta: Dinas Pendidikan Tinggi.

2. Jonanth, Hairy. 1989. Fisiologi Olahraga Jilid 1. Jakarta: Departemen Pendidikan dan Kebudayaan. Direktorat Jenderal Pendidikan Tinggi. Proyek Pengembangan Lembaga Pendidikan Tenaga Pendidikan.

3. Muhammad, Sajoto. 1988. Pembinaan Kondisi Fisik dalam Olahraga. Jakarta: PL2PTK, Dirjen Dikti Depdikbud.

4. Suharno, HP. 1993. Metodologi Pelatihan. Jakarta: Komite OLahraga Nasional Indonesia Pusat.

5. Syafaruddin. 2012. Altius Jurnal Ilmu OLahraga dan Kesehatan. Palembang: Universitas Sriwijaya

6. Syafruddin. 1992. Pengantar IImu Melatih. Padang: FPOK IKIP Padang

7. Syafruddin. 1999. Dasar-dasar Kepelatihan Olahraga. Padang: Fakultas Ilmu Keolahragaan Universitas Negerei Padang

8. Syafruddin. 2012. IImu Kepelatihan Olahraga. Padang: UNP Press 


\section{Author' biography}

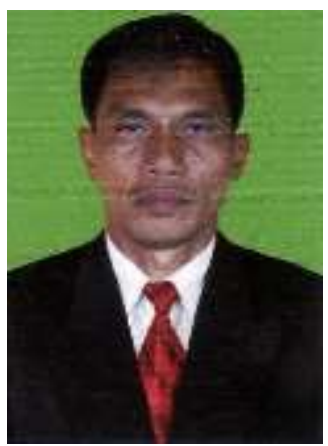

Firdaus Kamal, born in Jambi 12 Novembers 1962, was the second of Mr. H. Sutan Pameran (Alm)and Mrs. Hj. Elzas M. (from Bukittinggi).

Married to Agus nelly and happing a child nam ed Rahmat Al Azi z katialy, Student of PembangunanUNP Senior High School.

Education finish his Prim ary School in SD Negeri 01 Bajubang Jam bi in 1975, High School in Bajubang Jam bi in 1978, Senior Figh School in Bajubang Jam bi in 1981, and Sport Science Faclity, Ins titute a Science Theacher and Science Education of Padang in 1985, in 1997 continued Megister Program Sport Science in Airlangga Univercity and finisehed 1999, in 2009 continued Doctor

Program Sport Education Studies in Sem arang Univercity and finished 2012.

In 1987 appointed School Theacher Gym Teacher and in 1990 m ove d to the transition to Ins titute a Science Theacher and Science Education of Padang until now.Scientific Activities, Sport Science Thecnology (Scientific Papers, 1998), PB Pelti Ins tructur (Workshop, 1994), The Role of Secology, Psychology and Sports Bisiness in Supporting the Improvem en of Sports Performence (Sympos ium, 1997), Internas ional Tenis Federation Coaching Works hop (2000), Inters ection Scientific Work of Science and Thecnology of Sports (Workshop, 2007).

Scientific Work (Book), General Science of Sport (UPI Bandung, 2003), Sports Marketing (UPI Bandung, 2006), Sport Managem ent (UPI Bandung, 2008). 